\section{THREE UNUSUAL BRONCHOSCOPIC CASES}

A. TUMOR IN THE bRONCHUS. B. TRACHEAL STENOSIS. C. TRACHEAL SCLEROMA*

EMIL MAYER, M.D.

Laryngologist, Mount Sinul Hospltal; Chicf of the Nose, Throat and Ear Depultment, Mount Sinal llospltal Dlspensary Nlew YORK

(Ase 1.-Margaret 1. W., aged 3 years, was referrod to me Sept. 16, 1910, by Dr. Lim Emerson, presenting the following history:

History.-At the age of eleven days she had a sudden attrek of costruction to her breathing, whiclt yielded to treatment a fler a short time. Until January of the present year, she had been well. At this time she had an attack of grippe followed by a spasmodic cough, the latter remuining ever since. July 4, she hud an attack of measles, and on the 25 th her breathing became 6o interfered with that emphysema of the neck and body appeared, lasting several days. At the present time breathes with a loud expiratory eflort day and night. Has chronic constipation, prolupsus ani, and a capricious appetite.

Examination.-Child is well nourished and has goor color. l'here is a peculiar, loud respiration showing interference with the expiratory act. 'The reapirations are so loud as to be heard quite a distance and remain of this character day and night, becoming somewhat worse on crying or exertion. There is no rise of temperature, and the child plays about, getting easily tired, however. While she is never cyunosed, her dietress in breathing often culminates in un attack of vomiting, but without relief to the breathing. The examination of the chest sliows al sudden distention of the entire chest wall at each expiratory effort, except for the lower portion of the left lung. In this part there is dulness on pereussion and entire absemce of air entering the lung in the loft lower lobe. There is no bronchial catarrls. The diagnosis of some form of stenosis of the bronchus ut the bifurcation on the left side was made. An o-ray picture, taken by Dr. Jaches, radiographist of Mt. Sinai Hospital, showed an absence of air entering the lower lobe of the left lung. 'lhere was no evidence of any foreign body shown in the $x$-ray picture.

Operation.-At Mt. Sinui Hospital, under gas and ether. bronchoscopy was done on September 30, the instrument used being the Killian hand light with a short tube. 'The child took the unesthesia very badly und was very much cyanosed. The holding of the epiglottis incrensed the cyanosis to so mirked a degree that it was rapidly withdrawn. In the meantine, Dr. Funkauer, who ussisted me, lad a long tube attuched to another litilian hand light to which he had an attachment for the throwing of ether vapor into the tube during the entire examination, and at iny request he introdued the longer tube rapidly into the luonchus. At the bifurcation, directly over the entrunce to the left lumg, a new growth was seen having the generul appearnees of $\|$ papilloma; there seemed to be sereral of them with small pedicles and laving in all a diameter of one-half inch. 'These were promptly removed and after their jemoval the breathiner became very much freer, and uir again entered at the lower portion of the left lung. The growth was referred to 1)r. F. S. Mundelbaum, pathologist of Mt. Simai Hospital, who reported that, the growtl having been placed in formaldelyd solution, it was impossible to test for tubercle bucilli, but that the growti had all the appearances of syphilis.

Subsequent History.-The child recovered from the effects of the anestlosia, ajr frecly entering into the formerly obstructed lung, and on the third duy the child was sent to its bome.

live months later the examination of the child showed mo evidence of interference with respiration, the cough having gradually ceased, und the child was apparently well. In the meantime the child had been exumined by Dr. Sarn lielt liakels. whose report follows: "rvell-developed ehild for her age; weight $26 \%$ pounds; temperature normal. On the skin and visible inucosue nothing abnormal. Of the superficial Jymplatic glands, the anterior cervical and inguinal glunds are

- IRad before the Amorlen Jaryngological Association at it: thlsty-thlyd annual meeting, l'bliadelphia, 1611. slightly enlarged. The inspection of the buccal cavity shows a slight hypertrophy of the tonsils; voice and respiration are perfectly normal. Inspection of the thorax shows that the chest walls move freely during respiration, apparently sy $\mathrm{m}^{-}$ metrically on both sides; percussion over both lungs is clear and resonunt; lower borders of both lungs normal. On auscultation vesicular breathing is to be leeard, on and off hassh over all the lobes of the lungs; heart normal on percussion and auscultution; thymus dulness present. Of the organs of the abdomen, the spleen is not palpuble; the liver is very shightly enlarged; its lower border is one finger's breadth below tite costal arch in the nipple line, while in the median line it is slightly above a point midway between the umbilicus and the xyphoid process. The urine shows no trace of albumin or sugar. The feces show microscopically no pathologic constituents. The blood-count is as follows: Hemoglobin 70 per cent.; red blood-cells $3,600,000$; white blood-cells 10,200 ; differential count, polynuclears 59 per cent., small mononuclears 30 per cent., large niononuclears 8 per cent., eosinophils 3 per cent. Wassermanu's test was negative."

A most careful investigation into the family history as well as that of the child, shows no evidence of specific disense. A summary of the case shows that the clinical diagnosis of a stenosis of the bronchus at the entrance of the left lower lobe of the lung was fully established, and that a happy result followed the removal of the growth. This is a combination that is exceedingly rare.

('Ase 2.-Rose L., aged 12 years, an inmate of an orphan asylum, whose past history is necessarily indefinite, was referred to me Dec. 12,1910 , with the following history:

llistory.-lixcept for an uttack of diphtheria six years ago, followed by a protricted cough, she had been, as far as known, entirely well until four weeks ago when she began to cough, constuntly, spasmodically, and without secretion. There was a short, sharp, ringing cough with intervals of a few seconds, sounding more like the bark of a dog than a cough, rasping and very noisy. While not so frequent at night, still it occurred then. All manner of treatment had failed to relieve it; there was no dyspnea; the voice was clear, and there were no rales in the chest. It is almost impossible to express the extrenie amoyance to the child as also to its surroundings, occasioned by this noisy cough.

Hxamination.-The child had hypertrophied tonsils and an adenoid growth, but these were not considered as fuetors in causing cough. Below the chords, high up in the trachen, there was a trachenl thickening which showed itself not only in the laryngeal tissue but ulso by direct examination. 'The bronchoscopic tube was then introduced, and on its intro duction it was felt to puss through the firm constriction and the diagnosis of spasmodic cough due to a tracheal stenosis, probably post-diphtheritic, was made. The report of the findings wis made the following day to the attending physician, Dr. Gershel, who reported that, immediately following the bronchoscopy, all cough had ceased and this condition of curc of most distressing congh hus remained permanent from the single dilatation rollowing the entrance of the bronehoseopit tube. The general nppearance of the trachen at the time of examination clinically resembled those enses of trachenl scleroma that I have seren, and the diagnosis would have been iurestigated were it not for the fact that the child was born in the United States, and no case of this affection originating de noto in this country has ever been presented. The exanination with the bronchoscope was readily made under local anestlesia.

Cass 3.-Rachel R., nged 18 years, six years in the United Stuter, a native of Russian lolund, was adinitted to the surgical wards of Mt. Sinai Hospital, service of Dr. Hownd Lilienthal, two and a half years ago, suffering from dyspnea, requiring trachectomy. JBefore operating, Dr. Jilienthal requested me to see the case to determine the nature of the stenosis.

Firamination:-I found a tracheal thickening with much induration on the line of the cricoid cartilage, and much crust: formation in the nome with liyperplasia, and 1 made the elinic:al diagnosis of trucheal scleroma. A portion of the thickened tis- 
sue from the nose was removed and sent to the prithologic F. S. Mand for examination. 'The report came back from Dr. tive. Mandelbaum, chief of that depurtment, that it was newa. time it second portion was removed a few days later and this alvised was reported rhino-scleroma. Operation was not thal to the patient was then kindly referred by Dr. LilienDispensary out-patient department of the Mt. Simai Hospital was husky under my care. 'line dyspmea subsided, the voice tions until and the nasal secretions kept up their elust formaof tracheal a year ago when she began again to show symptoms of theal obstruction. From this time on dilatation by means the Killian tubes was practiced every week regularly with dilatation that the breathing became normal. Of late the night, and has ben done less frequently, about once a fortbronch and the patient is in a very comfortable condition. The has beople tube in this cass (niters very readily: the patient medical olerant and she has been exhibited at varions bronclical societies, ustally permitting the introduction of the alsence fopie tube in about thirty seconds' time. During my

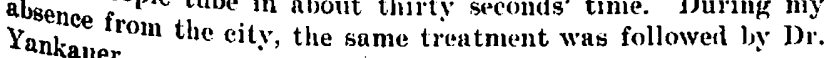
Thauer.

Thï case is of special interest in that most cases of tracheal scleroma lave heretolore d'equired trachectomy canether with the more or less constant wearing of the In This method is surely only palliative.

In presenting these three inusual cases. I conclucle establie correctness of the clinical diagnosis was fully cornpleted in the first case, while the happy result of which recovery followed the removal of the growth the abiled to show any symptoms of syphilis, and in growth a all tests must be put down as a henign as a main illustrating the value of the bronchoscope treatmeans of diagnosis and an assistance in the surgical In thent of these cases.

In the second and third cases, the bronchoscope was flist used as a means of diagnosis and then as a remedial agent, producing rule by rapicl cilation in one case, and giving decided relief in the other.

40 East Forty-lirst street.

\section{PLACENTA PRTIVIA-A WARNING}

\author{
J. F. BALDWIN, M.D. \\ Surgeon to Grant Hospital \\ coluarius, OHIO
}

Within the last two years an unusually large number of articles have appeared in the medical press on the subject of placenta prævia, the last article being the collaustive one by Ellice McDonald, in Surgery, Gyneent ${ }^{2}$, and Obstetrics, of Jume, 1911. In these differmandicles, and in the various text-books at my conmand, I fail to find any reference whatever to the poshad of concealed hemorrhage going on after the leg been brought down by the Braxton-Hicks method. 'That that is a very leal danger, however, thongh saw in saw in consultation about two years ago.

The patient was in charge of an unusually well-qualified mult physician, a graduate of Johns Hopkins. She was a havinara, whose previous labors had been easy. 'She had been delayg slight hemorrhages, but nothing alarming. Further the , however, being thought inadvisable, she was brought to in conpital for delivery, and I saw her then for the first time pronsultation. It was decided to adopt the Braxton-Hicks hrocedure, and with no difficulty I brought down a leg, as I nicely in very many previous, cases. The parts were dilating nicely, and thoroughly dilatable, so that it seemeu evident that no very would be accomplished in a short time. As there was no further need for my gervices I left the patient, her physicinn to ting steady traction, which scemed to put a complete stop to hemorrhage. Very little blood had been lost during the manipulation. Within an hour, and while $I$ was taking lunch in the hospital dining.room, an assistant came in und said that ho thought the attending physiciun would like to see me, ns tha pationt seemed to be going to pieces. I left the tuble instantly, and within a minnte was at the patient's bedside. She was dying in collapse, and a glance at the abdomen slowed the uterine tumor much larger than before, so that the diagnusis of internal hemorrhage was apparent. I directed the doctor to pull, while I exerted pressure above, and in an instant the elitd wats horn, the hirth being followed by such a deluge of blood and bloodeclots as I had never seen before. The patient was in arficulo mortis, and expired a very few moments after the child was delivered.

Since the above was written there have appeared, in the American Journal of Obstetrics, the papers which constituted a symposium on placenta pravia at the last meeting of the Imerican Gynecological Society. These papers are by Edwin B. Cragin, Edward P. Davis, J. Clifton Iidgar, Henry D. Fry and T. S. Newell. None ot' these paper's mentions the possibility of a concealed hemorrhage after the leg is brought down, while Fry speaks positively of "bleeding being absolutely under control" by this method, and advises slow delivery to prevent laceration of the lower uterine segment. A few juragraphs later he adds: "hemorrhage is controlled, and if the delivery is left to uterine action the dilatation is slow and safe."

Had the text-books contained any warning of the possilility of concealed hemorrhage going on in these cases, I think the attending plyssician would have been on his cruard and would have recognized the condition before the hemoryage hat reached a fatal stage.

I have had a rather large consultation experience in placenta prævia, and this is the only death from hemorthage of which I have had any personal knowledge, and this death can be looked on as in a sense unnecessary.

\section{A MODIFICATION OF SLUDER'S METHOD OF TONSILIECTOMY}

IUUTHER COLBY ROOD, M.D.

Visiting Surgeon for Discases of the Nose, Throat and Far to the Mount Sinal Hospital Bos'ron

'The purpose of this paper is to describe a modification of the method of guillotine tonsillectomy which Dr. Sluder advocated in Tirn Jounnal March 25, 1911, page $86 \%$. This modification has been used by me with murying success in seventeen cases; its results have proved equal to any dissection tonsillectomy operation formerly tried. It has invariably removed the tonsil and capsule completely, rapidly and bloodlessly. This modification consists in using the ordinary. tonsil snare, passed over the tonsil external to the already applied guillotine. Specitically, after the tonsil has been pressed through the window of the guillotine, by the alveolar eminence of the mandible, and engaged by the blade of the guillotine, in the manner described by Dr. Sluder, the distal end of the snare loop is passed over the guillotine and under guidance of the index-finger is placed posterior to, and thus external to, the tonsil and its capsule. Tightening the snare, in the usual manner for the particular snare, completes the removal.

In the use of this method it has not been found necessary to go in twice for any tonsil, however soft, shallow or imbedded. Dr. Sluder mentions the occasional need of going in a second time for remuants of tonsil or capsule. This is probably due to faulty technic, especially if this modification is used; for, if the tonsil is pressed through the guillotine so that the tonsil is drawn 